\title{
Pedobacter boryungensis sp. nov., isolated from soil
}

\author{
Yong-Taek Jung, ${ }^{1}$ Soo-Young Lee, ${ }^{1}$ Won-Chan Choi, ${ }^{1}$ Tae-Kwang Oh ${ }^{1}$ \\ and Jung-Hoon Yoon ${ }^{1,2}$ \\ ${ }^{1}$ Korea Research Institute of Bioscience and Biotechnology (KRIBB), PO Box 115, Yusong, \\ Taejon, Republic of Korea \\ ${ }^{2}$ Department of Food Science and Biotechnology, Sungkyunkwan University, Jangan-gu, \\ Suwon, Republic of Korea
}

\begin{abstract}
A Gram-negative, non-sporulating, non-flagellated rod, designated BR- $9^{\top}$, was isolated from soil collected on the Korean peninsula. Strain BR-9 ${ }^{\top}$ grew optimally at $\mathrm{pH} 6.0-7.0$, at $30{ }^{\circ} \mathrm{C}$ and in the absence of $\mathrm{NaCl}$. Phylogenetic analysis based on 16S rRNA gene sequences revealed that strain BR-9 ${ }^{\top}$ belonged to the genus Pedobacter and clustered with Pedobacter insulae DS-139 ${ }^{\top}$ and Pedobacter koreensis WPCB189 ${ }^{\top}$. Strain BR-9 ${ }^{\top}$ exhibited 98.2 and $97.5 \% 16 \mathrm{~S}$ rRNA gene sequence similarity with $P$. insulae DS $-139^{\top}$ and $P$. koreensis $\mathrm{WPCB}^{\mathrm{N}} \mathrm{9}^{\top}$, respectively, and $<96.7 \%$ sequence similarity with the type strains of other species in the genus Pedobacter. Strain BR- $9^{\top}$ contained MK-7 as the predominant menaquinone and iso- $\mathrm{C}_{15: 0}$ and summed feature $3\left(\mathrm{C}_{16: 1} \omega 7 \mathrm{c}\right.$ and/or iso- $\left.\mathrm{C}_{15: 0} 2-\mathrm{OH}\right)$ as the major fatty acids. The DNA $\mathrm{G}+\mathrm{C}$ content of strain BR-9 ${ }^{\top}$ was 38.5 mol\%. DNA-DNA relatedness between strain $\mathrm{BR}-9^{\top}$ and $P$. insulae DS $-139^{\top}$ and $P$. koreensis KCTC $12536^{\top}$ was $3.4-4.2 \%$, which indicated that the isolate was genetically distinct from these type strains. Strain $B R-9^{\top}$ was also distinguishable by differences in phenotypic properties. On the basis of the data presented, strain BR- $9^{\top}$ is considered to represent a novel species of the genus Pedobacter, for which the name Pedobacter boryungensis sp. nov. is proposed. The type strain is BR-9 $9^{\top}\left(=\right.$ KCTC $23344^{\top}=$ CCUG $\left.60024^{\top}\right)$.
\end{abstract}

The genus Pedobacter was proposed by Steyn et al. (1998) with the reclassification of two Sphingobacterium species and the description of two novel species. Recently, the number of described Pedobacter species has increased considerably. Interestingly, many novel Pedobacter species have been isolated from various regions of Korea (Hwang et al., 2006; Ten et al., 2006; Yoon et al., 2006, 2007a, b, c, d; Baik et al., 2007; Kwon et al., 2007; Roh et al., 2008; An et al., 2009; Lee et al., 2009; Jeon et al., 2009). At the time of writing, the genus Pedobacter comprised 32 species with validly published names (Euzéby, 1997, 2010). In this study, we report the taxonomic characterization of a Pedobacter-like bacterial strain, BR- $9^{\mathrm{T}}$, which was isolated from soil in Korea.

The standard dilution-plating technique was used for isolation of bacterial strains from surface soil samples collected from Boryung city. Strain BR-9 $9^{\mathrm{T}}$ was isolated on R2A agar (Difco) at $25{ }^{\circ} \mathrm{C}$ and routinely cultivated on R2A agar at $30{ }^{\circ} \mathrm{C}$. The type strains of two species of the genus Pedobacter were used as reference strains for DNA-DNA hybridization, phenotypic characterization and fatty acid

The GenBank/EMBL/DDBJ accession number for the 16S rRNA gene sequence of strain BR-9 ${ }^{\top}$ is $\mathrm{HM} 640986$. analysis. Pedobacter insulae DS-139 ${ }^{\mathrm{T}}$ was obtained in our previous study (Yoon et al., 2007b) and Pedobacter koreensis KCTC $12536^{\mathrm{T}}$ was obtained from the KCTC.

Cell morphology was examined using light microscopy (E600; Nikon) and transmission electron microscopy (CM20; Philips). Flagellation was investigated using cells from an exponentially growing culture. For this purpose, cells were negatively stained with $1 \%(\mathrm{w} / \mathrm{v})$ phosphotungstic acid and the grids were examined after being air-dried. Gliding motility was investigated as described by Bowman (2000). The Gram reaction was investigated using the bioMérieux Gram-stain kit, according to the manufacturer's instructions. Growth under anaerobic conditions was determined by incubation in a Forma anaerobic chamber on R2A agar and R2A agar supplemented with $0.1 \%(\mathrm{w} / \mathrm{v})$ potassium nitrate, both prepared under a nitrogen atmosphere. Growth at 4, 10, 20, 25, 30, 35 and $37{ }^{\circ} \mathrm{C}$ was measured on R2A agar. Growth at $\mathrm{pH} 4.5-10.5$ (in increments of $0.5 \mathrm{pH}$ units) was investigated in $\mathrm{R} 2$ broth (MBcell) after adjusting the $\mathrm{pH}$ with $\mathrm{HCl}$ or $\mathrm{Na}_{2} \mathrm{CO}_{3}$. The $\mathrm{pH}$ was verified after autoclaving. Growth with $0,0.5,1.0$ and $2.0 \%(\mathrm{w} / \mathrm{v}) \mathrm{NaCl}$ was investigated using trypticase soy broth prepared according to the formula of the Difco medium except that $\mathrm{NaCl}$ was 
omitted. Catalase and oxidase activities and hydrolysis of casein, gelatin, hypoxanthine, starch, Tweens 20, 40, 60 and 80 , tyrosine, urea and xanthine were determined as described by Cowan \& Steel (1965). Aesculin hydrolysis and nitrate reduction were studied as described by Lányí (1987) and $\mathrm{H}_{2} \mathrm{~S}$ production was tested as described by Bruns et al. (2001). Utilization of various substrates, enzyme activities and other physiological and biochemical properties were investigated using the API 20 NE, API 50 $\mathrm{CH}$ and API ZYM systems (bioMérieux); to inoculate the API $50 \mathrm{CH}$ system, cells were suspended in AUX medium, according to the manufacturer's instructions. Susceptibility to antibiotics was investigated on R2A agar using antibiotic discs containing the following ( $\mu \mathrm{g}$ per disc unless otherwise stated): ampicillin (10), carbenicillin (100), cephalothin (30), chloramphenicol (100), gentamicin (30), kanamycin (30), lincomycin (15), neomycin (30), novobiocin (5), oleandomycin (15), penicillin G (20 U), polymyxin B $(100 \mathrm{U})$, streptomycin (50) and tetracycline (30).

Cell biomass for DNA extraction and isoprenoid quinone analysis was obtained from cultures grown for 2 days in R2A broth at $30{ }^{\circ} \mathrm{C}$. Chromosomal DNA was extracted and purified according to the method described by Yoon et al. (1996), with the exception that RNase T1 was used in combination with RNase A to minimize contamination with RNA. The 16S rRNA gene was amplified by PCR using two universal primers, as described previously (Yoon et al., 1998), and the amplification products were purified using a QIAquick PCR purification kit (Qiagen). Sequencing and phylogenetic analysis were performed as described by Yoon et al. (2003). Isoprenoid quinones were extracted according to the method of Komagata \& Suzuki (1987) and analysed using reversed-phase HPLC and a YMC ODS-A $(250 \times 4.6 \mathrm{~mm})$ column. For cellular fatty acid analysis, cell mass of strain BR- $9^{\mathrm{T}}$, P. insulae DS- $139^{\mathrm{T}}$ and P. koreensis KCTC $12536^{\mathrm{T}}$ was harvested from R2A agar after cultivation for 3 days at $30{ }^{\circ} \mathrm{C}$. Fatty acids were saponified, methylated and extracted using the standard protocol of the Sherlock Microbial Identification System version 4.0 (Microbial ID). The fatty acids were analysed by GC (Hewlett Packard 6890) and identified using the TSBA40 database (Sasser, 1990). The DNA G+C content was determined by the method of Tamaoka \& Komagata (1984) with the modification that DNA was hydrolysed and the resultant nucleotides were analysed by reversed-phase HPLC. DNA-DNA hybridization was performed fluorometrically by the method of Ezaki et al. (1989) using photobiotin-labelled DNA probes and microdilution wells. Hybridization was performed with five replications for each sample; the highest and lowest values obtained for each sample were excluded and the means of the remaining three values are quoted as DNA-DNA relatedness.

The almost-complete 16S rRNA gene sequence of strain BR$9^{\mathrm{T}}$ obtained in this study comprised $1443 \mathrm{nt}$ and represented approximately $96 \%$ of the Escherichia coli $16 \mathrm{~S}$ rRNA gene sequence. In the phylogenetic tree constructed using the neighbour-joining algorithm, strain $\mathrm{BR}-9^{\mathrm{T}}$ fell within the genus Pedobacter and joined the cluster containing $P$. insulae DS- $139^{\mathrm{T}}$ and P. koreensis WPCB189 ${ }^{\mathrm{T}}$ (Fig. 1). The topology was supported by a bootstrap resampling value of $99.5 \%$ and was recovered in trees reconstructed using the maximum-likelihood and maximum-parsimony algorithms (Fig. 1). Strain BR-9 ${ }^{\mathrm{T}}$ exhibited 98.2 and $97.5 \% 16 \mathrm{~S}$ rRNA

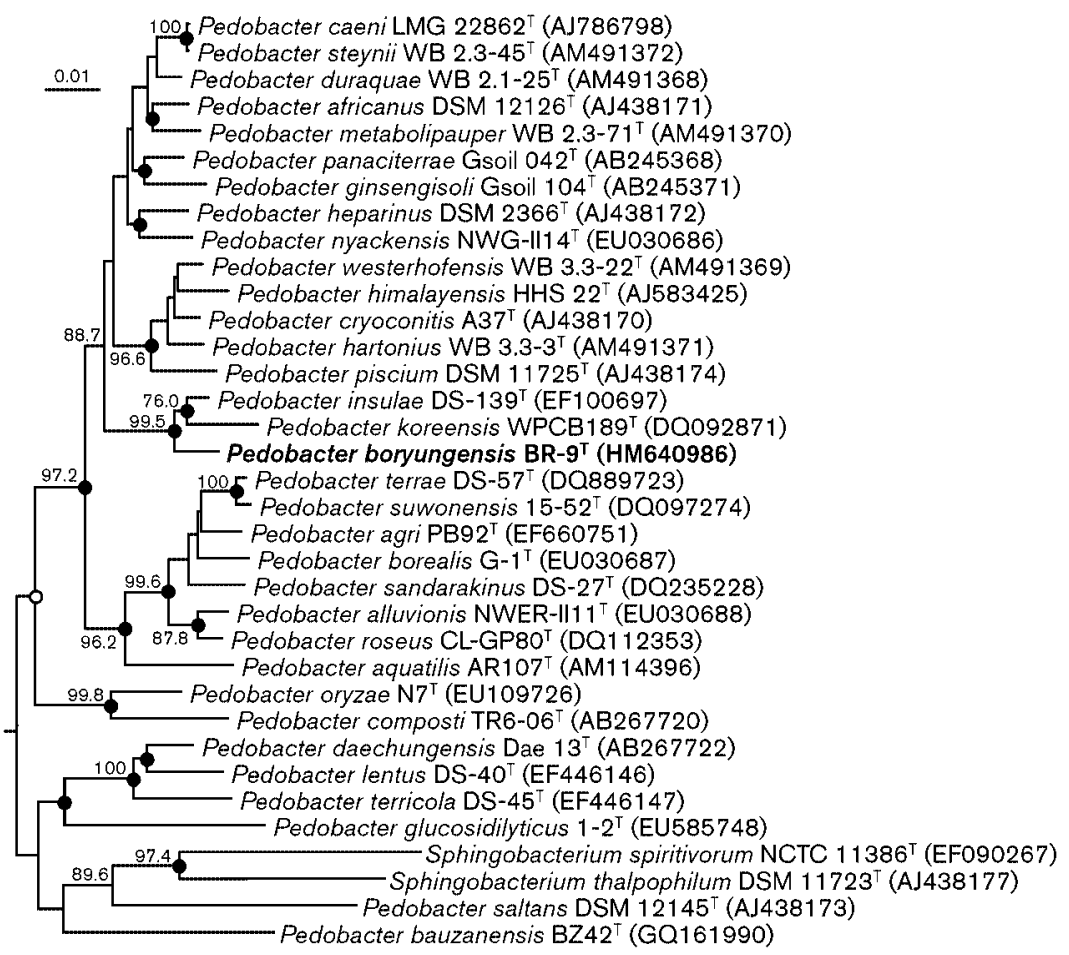

Fig. 1. Neighbour-joining phylogenetic tree based on 16S rRNA gene sequences showing the relationship of strain $B R-9^{\top}$ with members of the genus Pedobacter and some other related taxa. Bootstrap values $(>70 \%)$ based on 1000 replications are shown at branch nodes. Filled circles indicate that the corresponding nodes were also recovered in trees generated with the maximum-likelihood and maximum-parsimony algorithms. The open circle indicates that the corresponding node was also recovered in a tree generated with one of these algorithms. The sequence of Cytophaga hutchinsonii ATCC $33406^{\top}$ (GenBank accession no. M58768) was used as an outgroup (not shown). Bar, 0.01 substitutions per nucleotide position. 
gene sequence similarity to $P$. insulae DS- $139^{\mathrm{T}}$ and $P$. koreensis WPCB $189^{\mathrm{T}}$, respectively, and $<96.7 \%$ sequence similarity to the type strains of other species of the genus Pedobacter. The predominant isoprenoid quinone detected in strain BR-9 ${ }^{\mathrm{T}}$ was menaquinone-7 (MK-7), which is in agreement with that of members of the genus Pedobacter (Steyn et al., 1998). The fatty acid profile of strain BR- $9^{\mathrm{T}}$ is shown in Table 1, together with those obtained in this study for the reference strains. The fatty acid profiles of the three strains were similar, although there were differences in the proportions of some fatty acids (Table 1). The DNA G+C content of strain $B R-9^{T}$ was $38.5 \mathrm{~mol} \%$, which is similar to those reported for $P$. insulae and P. koreensis (39.4 and $38.0 \mathrm{~mol} \%$, respectively) and most other Pedobacter species.

Strain BR-9 $9^{\mathrm{T}}$ exhibited 3.4 and $4.2 \%$ DNA-DNA relatedness to P. insulae DS- $139^{\mathrm{T}}$ and P. koreensis KCTC $12536^{\mathrm{T}}$,

Table 1. Cellular fatty acid compositions of strain $B R-9^{\top}$ and its closest phylogenetic neighbours

Strains: 1, Pedobacter boryungensis sp. nov. BR-9 $9^{\mathrm{T}} ; 2$, P. insulae DS$139^{\mathrm{T}}$; 3. P. koreensis KCTC $12536^{\mathrm{T}}$. All data were taken from this study. Fatty acids that represented $<0.5 \%$ in all strains are omitted. tr, Trace $(<0.5 \%)$; - , not detected; ECL, equivalent chain-length.

\begin{tabular}{|c|c|c|c|}
\hline Fatty acid & 1 & 2 & 3 \\
\hline \multicolumn{4}{|l|}{ Straight-chain } \\
\hline $\mathrm{C}_{14: 0}$ & 0.8 & 1.1 & 3.6 \\
\hline $\mathrm{C}_{15: 0}$ & 6.9 & 1.7 & 2.7 \\
\hline $\mathrm{C}_{16: 0}$ & 2.0 & 3.8 & 12.1 \\
\hline \multicolumn{4}{|l|}{ Unsaturated } \\
\hline $\mathrm{C}_{15: 1} \omega 6 c$ & 4.8 & 1.5 & 0.8 \\
\hline $\mathrm{C}_{16: 1} \omega 5 c$ & 0.9 & 1.1 & 2.4 \\
\hline \multicolumn{4}{|l|}{ Branched } \\
\hline iso- $\mathrm{C}_{14: 0}$ & 1.1 & - & 0.8 \\
\hline iso- $\mathrm{C}_{15: 0}$ & 29.9 & 26.1 & 26.3 \\
\hline anteiso- $\mathrm{C}_{15: 0}$ & 1.9 & 2.6 & 3.8 \\
\hline iso- $\mathrm{C}_{16: 0}$ & 3.0 & 3.0 & 3.3 \\
\hline iso- $\mathrm{C}_{16: 1} \mathrm{H}^{*}$ & 1.5 & 2.2 & 0.6 \\
\hline iso- $\mathrm{C}_{17: 0}$ & $\operatorname{tr}$ & $\operatorname{tr}$ & 0.6 \\
\hline iso- $\mathrm{C}_{17: 1} \omega 9 c$ & 1.6 & 4.4 & 0.7 \\
\hline anteiso- $\mathrm{C}_{17: 1} \omega 9 c$ & 1.0 & 2.0 & - \\
\hline \multicolumn{4}{|l|}{ Hydroxy } \\
\hline $\mathrm{C}_{15: 0} 2-\mathrm{OH}$ & 1.7 & 2.0 & 1.1 \\
\hline iso- $\mathrm{C}_{15: 0} 3-\mathrm{OH}$ & 2.5 & 2.8 & 1.8 \\
\hline $\mathrm{C}_{16: 0} 3-\mathrm{OH}$ & 0.7 & 0.6 & 2.6 \\
\hline iso- $\mathrm{C}_{16: 0} 3-\mathrm{OH}$ & 5.2 & 3.5 & 5.7 \\
\hline $\mathrm{C}_{17: 0} 2-\mathrm{OH}$ & 2.2 & 5.5 & 4.6 \\
\hline iso- $\mathrm{C}_{17: 0} 3-\mathrm{OH}$ & 6.7 & 8.1 & 6.1 \\
\hline Summed feature $3 \dagger$ & 17.8 & 24.4 & 17.4 \\
\hline Unknown ECL 13.565 & 1.4 & 1.1 & 1.0 \\
\hline
\end{tabular}

*The double bond position indicated by the capital letter is unknown. $\uparrow$ Summed features represent groups of two or three fatty acids that cannot be separated by the Microbial Identification System. Summed feature 3 consisted of $\mathrm{C}_{16: 1} \omega 7 c$ and/or iso- $\mathrm{C}_{15: 0} 2-\mathrm{OH}$.
Table 2. Differential phenotypic characteristics of strain BR-9 ${ }^{\top}$ and its closest phylogenetic neighbours

Strains: 1 , P. boryungensis sp. nov. BR $-9^{\mathrm{T}} ; 2$, P. insulae DS- $139^{\mathrm{T}} ; 3, P$. koreensis KCTC $12536^{\mathrm{T}}$. Data were obtained in this study or taken from Yoon et al. (2007b) and Baik et al. (2007). All strains are positive for catalase, hydrolysis of aesculin, starch, Tweens 20, 40, 60 and 80 and L-tyrosine, assimilation of D-glucose and D-mannose, susceptibility to chloramphenicol, gentamicin, lincomycin, novobiocin and tetracycline and activities of alkaline phosphatase, leucine arylamidase, valine arylamidase, acid phosphatase, naphthol-AS-BI-phosphohydrolase and $N$-acetyl- $\beta$-glucosaminidase. All strains are negative for gliding motility, anaerobic growth, Gram staining, nitrate reduction, hydrolysis of casein, gelatin, hypoxanthine, urea and xanthine, assimilation of malate, citrate, phenylacetate, erythritol, $\mathrm{D}$-arabinose, L-xylose, methyl $\beta$-D-xyloside, D-fructose, L-sorbose, dulcitol, inositol, D-mannitol, D-sorbitol, inulin, melezitose, raffinose, xylitol, D-tagatose, D- and L-fucose, D- and L-arabitol, 2-ketogluconate and 5-ketogluconate, susceptibility to ampicillin and activities of esterase (C4), esterase lipase (C8), lipase (C14), trypsin, $\beta$ glucuronidase, $\beta$-glucosidase, $\alpha$-mannosidase and $\alpha$-fucosidase. + , Positive; $w$, weakly positive; - , negative.

\begin{tabular}{|c|c|c|c|}
\hline Characteristic & 1 & 2 & 3 \\
\hline Optimal temperature $\left({ }^{\circ} \mathrm{C}\right)$ & 30 & 25 & 25 \\
\hline Oxidase & + & + & - \\
\hline \multicolumn{4}{|l|}{ Assimilation (API $50 \mathrm{CH}$ ) of: } \\
\hline Glycerol & - & + & - \\
\hline L-Arabinose & - & + & - \\
\hline D-Ribose & - & - & + \\
\hline D-Xylose & - & + & + \\
\hline D-Adonitol & - & + & - \\
\hline D-Galactose & - & - & + \\
\hline L-Rhamnose & - & $\mathrm{W}$ & - \\
\hline Methyl $\alpha$-D-mannoside & - & $\mathrm{W}$ & - \\
\hline Methyl $\alpha$-D-glucoside & - & + & - \\
\hline$N$-Acetylglucosamine & + & + & - \\
\hline Amygdalin & - & + & - \\
\hline Arbutin & $\mathrm{w}$ & + & - \\
\hline Salicin & - & + & - \\
\hline Cellobiose & - & + & + \\
\hline Maltose & - & + & + \\
\hline Lactose & - & + & + \\
\hline Melibiose & - & + & - \\
\hline Trehalose & - & + & - \\
\hline Starch & - & + & - \\
\hline Glycogen & - & + & + \\
\hline Gentiobiose & - & + & + \\
\hline Turanose & - & $\mathrm{w}$ & - \\
\hline \multicolumn{4}{|l|}{ Susceptibility to: } \\
\hline Streptomycin & + & + & - \\
\hline Penicillin G & - & + & - \\
\hline \multicolumn{4}{|l|}{ Enzyme activities (API ZYM) } \\
\hline Cystine arylamidase & $\mathrm{w}$ & - & - \\
\hline$\alpha$-Chymotrypsin & - & + & - \\
\hline$\alpha$-Galactosidase & + & - & - \\
\hline$\beta$-Galactosidase & - & - & + \\
\hline$\alpha$-Glucosidase & + & + & - \\
\hline
\end{tabular}


respectively. These values indicate that strain $B R-9^{\mathrm{T}}$ represents a genomic species distinct from these two Pedobacter species (Wayne et al., 1987). The phenotypic characteristics of strain BR- $9^{\mathrm{T}}$ were compared with those of the reference strains determined using the same methods (Yoon et al., 2007b; Baik et al., 2007; Table 2). Strain BR-9 ${ }^{\mathrm{T}}$ could be differentiated from the reference strains by differences in some phenotypic characteristics, including assimilation of various substrates, activity of several enzymes and susceptibility to several antibiotics.

The phylogenetic distinctiveness, together with DNA-DNA relatedness and differential phenotypic properties, is sufficient to allocate strain BR-9 $9^{\mathrm{T}}$ to a species that is separate from recognized members of the genus Pedobacter (Stackebrandt \& Goebel, 1994). Therefore, on the basis of the data presented, strain BR- $9^{\mathrm{T}}$ is considered to represent a novel species of the genus Pedobacter, for which the name Pedobacter boryungensis sp. nov. is proposed.

\section{Description of Pedobacter boryungensis sp. nov.}

Pedobacter boryungensis (bo.ry.un.gen'sis. N.L. masc. adj. boryungensis pertaining to Boryung, the Korean city from where the type strain was isolated).

Cells are Gram-negative, non-sporulating, non-flagellated rods $(0.2-0.5 \times 2.0-5.0 \mu \mathrm{m})$. Colonies on R2A agar are circular, convex, smooth, glistening, pale yellow and 0.5$1.0 \mathrm{~mm}$ in diameter after incubation for 2 days at $30{ }^{\circ} \mathrm{C}$. Optimal temperature for growth is $30{ }^{\circ} \mathrm{C}$; grows at 4 $35^{\circ} \mathrm{C}$, but not at $37^{\circ} \mathrm{C}$. Optimal pH for growth is $\mathrm{pH} 6.0$ 7.0; grows at $\mathrm{pH} 5.5$, but not at $\mathrm{pH}$ 5.0. Optimal growth occurs without $\mathrm{NaCl}$; grows with $1.0 \%(\mathrm{w} / \mathrm{v}) \mathrm{NaCl}$, but not with $2.0 \%(\mathrm{w} / \mathrm{v}) \mathrm{NaCl}$. Anaerobic growth does not occur on R2A agar or R2A agar supplemented with nitrate. $\mathrm{H}_{2} \mathrm{~S}$ is not produced. Sucrose, D-lyxose and gluconate are not utilized as sole carbon and energy sources. Susceptible to cephalothin, chloramphenicol, gentamicin, lincomycin, novobiocin, polymyxin B, streptomycin and tetracycline, but not to ampicillin, carbenicillin, kanamycin, neomycin, penicillin $\mathrm{G}$ or oleandomycin. The predominant menaquinone is MK-7. The major fatty acids ( $>10 \%$ of the total) are iso- $\mathrm{C}_{15: 0}$ and summed feature $3\left(\mathrm{C}_{16: 1} \omega 7 \mathrm{c}\right.$ and/or iso- $\left.\mathrm{C}_{15: 0} 2-\mathrm{OH}\right)$. The DNA G $+\mathrm{C}$ content of the type strain is $38.5 \mathrm{~mol} \%$ (HPLC). Other phenotypic characteristics are given in Table 1.

The type strain, BR- $9^{\mathrm{T}}\left(=\right.$ KCTC $23344^{\mathrm{T}}=$ CCUG $\left.60024^{\mathrm{T}}\right)$, was isolated from soil in Boryung city, on the Korean peninsula.

\section{Acknowledgements}

This work was supported by the 21C Frontier Program of Microbial Genomics and Applications (grant no. 11-2008-00-002-00) and the Program for Collection, Management and Utilization of Biological Resources (grant no. M10867010003) from the Ministry of Education, Science and Technology (MEST), Republic of Korea.

\section{References}

An, D.-S., Kim, S.-G., Ten, L. N. \& Cho, C.-H. (2009). Pedobacter daechungensis sp. nov., from freshwater lake sediment in South Korea. Int J Syst Evol Microbiol 59, 69-72.

Baik, K. S., Park, Y.-D., Kim, M. S., Park, S. C., Moon, E. Y., Rhee, M. S., Choi, J. H. \& Seong, C. N. (2007). Pedobacter koreensis sp. nov., isolated from fresh water. Int J Syst Evol Microbiol 57, 2079-2083.

Bowman, J. P. (2000). Description of Cellulophaga algicola sp. nov., isolated from the surfaces of Antarctic algae, and reclassification of Cytophaga uliginosa (ZoBell and Upham 1944) Reichenbach 1989 as Cellulophaga uliginosa comb. nov. Int J Syst Evol Microbiol 50, 1861-1868.

Bruns, A., Rohde, M. \& Berthe-Corti, L. (2001). Muricauda ruestringensis gen. nov., sp. nov., a facultatively anaerobic, appendaged bacterium from German North Sea intertidal sediment. Int J Syst Evol Microbiol 51, 1997-2006.

Cowan, S. T. \& Steel, K. J. (1965). Manual for the Identification of Medical Bacteria. London: Cambridge University Press.

Euzéby, J. P. (1997). List of bacterial names with standing in nomenclature: a folder available on the Internet. Int J Syst Bacteriol 47, 590-592.

Euzéby, J. P. (2010). List of prokaryotic names with standing in nomenclature. Last full update 5 August 2010. http://www.bacterio. cict.fr/p/pedobacter.html

Ezaki, T., Hashimoto, Y. \& Yabuuchi, E. (1989). Fluorometric deoxyribonucleic acid-deoxyribonucleic acid hybridization in microdilution wells as an alternative to membrane filter hybridization in which radioisotopes are used to determine genetic relatedness among bacterial strains. Int J Syst Bacteriol 39, 224-229.

Hwang, C. Y., Choi, D. H. \& Cho, B. C. (2006). Pedobacter roseus sp. nov., isolated from a hypertrophic pond, and emended description of the genus Pedobacter. Int J Syst Evol Microbiol 56, 1831-1836.

Jeon, Y., Kim, J. M., Park, J. H., Lee, S. H., Seong, C.-N., Lee, S.-S. \& Jeon, C. O. (2009). Pedobacter oryzae sp. nov., isolated from rice paddy soil. Int J Syst Evol Microbiol 59, 2491-2495.

Komagata, K. \& Suzuki, K. (1987). Lipid and cell-wall analysis in bacterial systematics. Methods Microbiol 19, 161-207.

Kwon, S.-W., Kim, B.-Y., Lee, K.-H., Jang, K.-Y., Seok, S.-J., Kwon, J.-S., Kim, W.-G. \& Weon, H.-Y. (2007). Pedobacter suwonensis sp. nov., isolated from the rhizosphere of Chinese cabbage (Brassica campestris). Int J Syst Evol Microbiol 57, 480-484.

Lányí, B. (1987). Classical and rapid identification methods for medically important bacteria. Methods Microbiol 19, 1-67.

Lee, H.-G., Kim, S.-G., Im, W.-T., Oh, H.-M. \& Lee, S.-T. (2009). Pedobacter composti sp. nov., isolated from compost. Int J Syst Evol Microbiol 59, 345-349.

Roh, S. W., Quan, Z.-X., Nam, Y.-D., Chang, H.-W., Kim, K.-H., Kim, M.-K., Im, W.-T., Jin, L., Kim, S.-H. \& other authors (2008). Pedobacter agri sp. nov., from soil. Int J Syst Evol Microbiol 58, 1640-1643.

Sasser, M. (1990). Identification of bacteria by gas chromatography of cellular fatty acids, MIDI Technical Note 101. Newark, DE: MIDI Inc.

Stackebrandt, E. \& Goebel, B. M. (1994). Taxonomic note: a place for DNA-DNA reassociation and $16 \mathrm{~S}$ rRNA sequence analysis in the present species definition in bacteriology. Int J Syst Bacteriol 44, 846849.

Steyn, P. L., Segers, P., Vancanneyt, M., Sandra, P., Kersters, K. \& Joubert, J. J. (1998). Classification of heparinolytic bacteria into a new genus, Pedobacter, comprising four species: Pedobacter heparinus comb. nov., Pedobacter piscium comb. nov., Pedobacter africanus sp. nov. and Pedobacter saltans sp. nov. Proposal of the family Sphingobacteriaceae fam. nov. Int J Syst Bacteriol 48, 165-177. 
Tamaoka, J. \& Komagata, K. (1984). Determination of DNA base composition by reversed-phase high-performance liquid chromatography. FEMS Microbiol Lett 25, 125-128.

Ten, L. N., Liu, Q.-M., Im, W.-T., Lee, M., Yang, D.-C. \& Lee, S.-T. (2006). Pedobacter ginsengisoli sp. nov., a DNase-producing bacterium isolated from soil of a ginseng field in South Korea. Int J Syst Evol Microbiol 56, 2565-2570.

Wayne, L. G., Brenner, D. J., Colwell, R. R., Grimont, P. A. D., Kandler, O., Krichevsky, M. I., Moore, L. H., Moore, W. E. C., Murray, R. G. E. \& other authors (1987). Report of the ad hoc committee on reconciliation of approaches to bacterial systematics. Int J Syst Bacteriol 37, 463-464.

Yoon, J.-H., Kim, H., Kim, S.-B., Kim, H.-J., Kim, W. Y., Lee, S. T., Goodfellow, M. \& Park, Y.-H. (1996). Identification of Saccharomonospora strains by the use of genomic DNA fragments and rRNA gene probes. Int J Syst Bacteriol 46, 502-505.

Yoon, J.-H., Lee, S. T. \& Park, Y.-H. (1998). Inter- and intraspecific phylogenetic analysis of the genus Nocardioides and related taxa based on 16S rDNA sequences. Int J Syst Bacteriol 48, 187-194.
Yoon, J.-H., Kang, K. H. \& Park, Y.-H. (2003). Psychrobacter jeotgali sp. nov., isolated from jeotgal, a traditional Korean fermented seafood. Int J Syst Evol Microbiol 53, 449-454.

Yoon, J.-H., Lee, M.-H., Kang, S.-J., Park, S.-Y. \& Oh, T.-K. (2006). Pedobacter sandarakinus sp. nov., isolated from soil. Int J Syst Evol Microbiol 56, 1273-1277.

Yoon, M.-H., Ten, L. N., Im, W.-T. \& Lee, S.-T. (2007a). Pedobacter panaciterrae sp. nov., isolated from soil in South Korea. Int J Syst Evol Microbiol 57, 381-386.

Yoon, J.-H., Kang, S.-J., Oh, H. W. \& Oh, T.-K. (2007b). Pedobacter insulae sp. nov., isolated from soil. Int J Syst Evol Microbiol 57, 19992003.

Yoon, J.-H., Kang, S.-J., Park, S. \& Oh, T.-K. (2007c). Pedobacter lentus sp. nov. and Pedobacter terricola sp. nov., isolated from soil. Int J Syst Evol Microbiol 57, 2089-2095.

Yoon, J.-H., Kang, S.-J. \& Oh, T.-K. (2007d). Pedobacter terrae sp. nov., isolated from soil. Int J Syst Evol Microbiol 57, 24622466. 